\title{
Oedipus and Tiresias: $\mathrm{Im} /$ politeness Theory and the Interpretation of Sophocles' Oedipus Tyrannus
}

\author{
Luigi Battezzato
}

\section{1 \\ Theoretical Approaches: Politeness Theory, Theory of Mind, and Possible-World Theory}

The present paper analyses the dialogue between Oedipus and Tiresias in Oedipus the King (297-462) from three angles: politeness theory, theory of mind, and theory of possible worlds. The paper will argue that the approaches are compatible from a theoretical point of view and complement each other. Politeness theory helps us make sense of the dialogue at the micro-level; theory of mind and theory of possible worlds can be fruitfully combined with politeness theory to make sense of the whole dialogic sequence.

These approaches are crucial for understanding the two main interpretive problems of the scene: Oedipus' shift from politeness to impoliteness and Tiresias' (apparent?) incoherence. Oedipus is, at first, extremely polite to Tiresias but ends up having one of the most aggressive clashes known in Greek tragedy. Tiresias, on arriving onstage, refuses to reveal what he knows about the killer of Laius (316-333); he then reveals the truth (350-442); at the end, he claims that he has said 'what I came here for' $(447),{ }^{1}$ thus suggesting in retrospect that his original intention was the opposite of what he said. ${ }^{2}$

Most pragmatic theories focus on short dialogic or textual sequences. Conversation Analysis and politeness theory developed from pioneering studies of the 1970s, by Sacks as well as Brown and Levinson respectively, and developed into a highly formalised subfield of linguistics. ${ }^{3}$ Brown and Levinson's frame-

1 Unless indicated otherwise, all references in the paper are to Sophocles' Oedipus the King; the Greek text and the translation are taken from Finglass (2018). I thank the volume editors, Marco Catrambone, and Catherine Conybeare for useful comments and corrections. The Università del Piemonte Orientale contributed to support this piece of research.

2 On this scene, see esp. Lattimore (1975), Reinhardt (1979: 104-110), Bain (1979), Heath (1987: 149-151), Ahl (1991: 67-102), Gianquinto (1994), Pfeiffer-Petersen (1996: 74-85), Edmunds (2000), Dorati (2015: 205-209), Worman (2014), Manuwald (2012a), Condello (2016), and Finglass (2018: ad 297-462) with further references.

3 On conversation analysis, see Sacks et al. (1974), Sidnell (2010); Sidnell and Stivers (2012); for classics, see van Emde Boas (2017a), van Emde Boas (2017b). On politeness theory, see the following note. 
work is now widely used, ${ }^{4}$ in spite of criticism. ${ }^{5}$ Some of the more general concepts introduced by Brown and Levinson are heuristically useful: 'face redress', 'bald on record', positive and negative face (respectively the 'positive consistent self-image' and the wish that one's action 'be unimpeded by others'), ${ }^{6}$ and 'off record. ${ }^{7}$ Of special importance for the present paper is the concept of being 'off record', which describes a 'communicative act' which 'is done in such a way that it is not possible to attribute only one clear communicative intention to the act'. ${ }^{8}$ Applying this methodology to ancient texts involves special problems: for instance, intonation is normally crucial for evaluating ironic or insulting passages, but the intonation of an ancient Greek is inaccessible for us. Moreover, bald-on-record and off-record utterances are potentially ambiguous, since they can be used in polite, ironic, or insulting ways. It is not simple to determine these nuances and objective criteria are difficult to find. This is especially complex in the case of the scene that is to be studied, which stages an angry quarrel which includes many ironic statements. ${ }^{9}$

A second problematic area is the ambiguity of 'politeness' itself: does it refer to the interpretation of speakers in the conversation ('first-order politeness' or 'politenessi') or is it simply a theoretical construct ('second-order politeness' or 'politeness2'), or a label to describe a linguistic strategy which may be actually impolite? ${ }^{10}$ We will see that Oedipus and Tiresias use 'polite' strategies, such as the 'off-record' strategy defined above, but that their clash is actually impolite.

Brown and Levinson based their approach on Grice's theory of language, in particular on his principle of co-operation..$^{11}$ Grice, in turn, presupposes 'rationality' as a general principle of human behaviour and linguistic interaction. Many scholars question whether this model is useful for all conversations (human beings often act irrationally ${ }^{12}$ and fail or refuse to co-operate) and

Brown and Levinson ( ${ }^{2} 1987$ ), Lloyd (2004), Brown (2006), Lloyd (2006), Lloyd (2009), Ferri (2009), Hall (2009), Barrios-Lech (2016), Catrambone (2016), van Emde Boas (2017b), and Catrambone (2019).

$5 \quad$ See e.g. Watts (2003).

6 See Brown and Levinson (21987: 61-62) and passim. Positive and negative politeness are linguistic strategies that try to 'redress' or minimise the threats that a linguistic act poses against the positive and negative face of the interlocutor.

7 For methodological discussions and definitions, see above, n. 4.

8 Brown and Levinson ( ${ }^{2} 1987$ : 211). For an extensive discussion of the phenomenon in Sophocles, see Catrambone (2016).

9 See esp. 364, 432, 435-436, 440.

10 Watts (2003: 8-9); Culpeper (2011: 396-397).

11 Grice $(1975: 45=1989: 26)$.

12 On irrationality in psychology, see e.g. Kahneman (2011); on the linguistic implications of this, see Culpeper (2011: 32), with references. 
whether it can really account for non-polite conversations (in what way is an angry argument a co-operative linguistic exchange?). As Culpeper points out:

Grice was aware of problematic cases such as quarrelling, which is why his description of the Cooperative Principle refers not only to 'a common purpose or set of purposes' but adds 'or at least a mutually accepted direction.'13

These three main problematic areas relate to the fact that, in order to interpret the dynamics of the conversation, we need to infer the 'intentions' of the speakers. ${ }^{14}$ We can do that from the general drift of the dialogue and/or from statements from the speakers, but we should bear in mind that, as Haugh points out, intention is often a post-factum construct. ${ }^{15}$

This does not stop human beings from attributing intentions and states of minds to other human beings, mostly on the basis of their actions and words. This mental faculty is called Theory of Mind (ToM); it is an endowment peculiar to the human species. ${ }^{16}$ Human beings use ToM in order to interpret both real people and fictional characters. As Zunshine notes:

Works of fiction manage to 'cheat' these mechanisms [i.e. ToM cognitive mechanisms] into 'believe' that they are in the in the presence of material that they were 'designed' to process, that is, that they are in the presence of agents endowed with a potential for a rich array of intentional stances. ${ }^{17}$

A growing corpus of research focuses on ToM in ancient and modern fiction. ${ }^{18}$

ToM focuses on long narrative and dialogic sequences. Even larger sections of narrative texts are discussed in 'possible-world theories', i.e. theories that discuss narrative as a set of possible worlds. When a story is communicated to an audience (of readers, spectators, etc.), the audience imagines possible ways in which the story could evolve or reconstruct past events in the world of fiction. ${ }^{19}$ These possible worlds are part of the mental image of the recipi-

\footnotetext{
13 Culpeper (2011: 158) referring to Grice (1989: 26). See also Culpeper (2011: 32).

14 On intentions in pragmatics, see Haugh (2008), Haugh and Jaszczolt (2012).

15 Haugh (2008: 101).

16 On ToM in general, see e.g. Apperly (2012), Epley (2014), Heyes (2018).

17 Zunshine (2006: 10).

18 On ToM and fiction, see Zunshine (2006), Herman (2013); see also the papers collected in Zunshine (2015). On ToM and Greek texts, see Budelmann and Easterling (2010), Scodel (2012), Battezzato (2019).

19 See e.g. the early approaches of Iser (1978).
} 
ents of a narrative. Ryan pointed out that readers imagine fictional worlds as the closest possible to the 'actual' world, and they only make changes that are mandated by the text. Ryan calls this interpretive rule 'the principle of minimal departure. ${ }^{20}$ Applying our innate mind-reading abilities (or ToM) to literary characters amounts to subjecting them to the principle of minimal departure. ToM is thus crucial for these approaches (politeness theory, conversation analysis, possible-world theory), which are often applied one by one rather than combined.

The possible-world theory is especially useful for interpreting texts in which fate and prophecies play a part, such as Oedipus the King. Is the storyworld of the play totally determined by fate? Or is it only partially determined? How can knowledge of future events and freedom coexist? And what do characters think about their own freedom of action? These questions will be explored in section 3 .

\section{Oedipus and Tiresias}

After many years in a department, a friend of mine moved to a different academic institution. This friend was unhappy: 'I cannot quarrel well with my new colleagues.' Quarrels require linguistic collaboration: people need to continue to speak and, in order to do so, must understand each other at least in part. In Greek tragedy, quarrels may end in walkouts and/or silence. ${ }^{21}$ Quarrels normally entail impoliteness, and impoliteness, just like politeness, can be a strategy to achieve a goal. Culpeper, in one of the most important contributions to this topic, distinguishes between affective, coercive, and entertaining impoliteness. ${ }^{22}$ It is easy to find examples of affective and coercive impoliteness in Greek tragedy. ${ }^{23}$ Do these categories apply to the dialogue between Tiresias

$20 \quad$ See Ryan $(1991,2013)$. Dorati (2015) discusses these theories in relation to ancient Greek texts.

21 See esp. Iurescia and Martin (2019). Many quarrels end when a character leaves whilst making a final parting statement (see e.g. in Soph. Aj. 1159-116o, Phil. 1257-1258, oc 10361037 and 1443-1446). On scenes of quarrel in Sophocles in general, see Pfeiffer-Petersen (1996).

22 Culpeper (2011: 221-239).

23 According to Culpeper (2011: 59), affective impoliteness 'is characterised by the fact that it is emotionally driven'; see e.g. Soph. Phil. 991. According to Culpeper (2011: 226), '[c] oercive impoliteness is impoliteness that seeks a realignment of values between the producer and the target such that the producer benefits or has their current benefits reinforced or protected [...]. It involves coercive action that is not in the interest of the target.' For 
and Oedipus in Oedipus the King? Bain considers this scene a 'psychologically convincing depiction of a quarrel between two angry men'24 but some difficulties are evident. Oedipus and Tiresias, in their quarrel, accuse each other of the gravest crimes but fail to understand each other. They act and speak in a way that has been judged incongruous by many interpreters. Voltaire claimed that the incongruity derives from Sophocles' incompetence as a playwright:

So much ignorance in Oedipus and Jocasta is only a crude artifice of the poet, who, to give his play a reasonable length, spins out into the fifth act a realisation already made obvious in the second. ${ }^{25}$

Tycho von Wilamowitz-Moellendorff claimed that the scene between Tiresias and Oedipus was 'far removed from all psychological subtleties'. ${ }^{26}$ Reinhardt considered Tiresias inherently incoherent: 'indecisive and forgetful, coming and yet anxious to go, concealing and yet revealing; he is half a capricious, irritable old man, half-in the midst of his anger-possessed of second sight; he is a walking enigma.'. ${ }^{27}$

The main inconsistency concerns Tiresias' intentions. When he arrives onstage, he refuses to reveal what he knows:

[1] Sophocles Oedipus the King 332-333

$$
\text { ... } \tau^{\prime} \tau \alpha \hat{\tau} \tau^{\prime}
$$

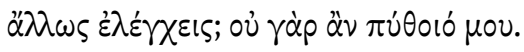

Why do you pointlessly carry out this investigation? For you will not learn anything from me.

examples in tragedy, see [9] (Soph. oт 334-336) and Creon's utterances in Soph. Ant. 280331. According to Culpeper (2011: 234), entertaining impoliteness is 'designed as much for the over-hearing audience as for the target addressee' and aims at entertaining the audience. In fact, entertainment can be a side effect of coercive impoliteness (I thank G. Martin for pointing out this problem in Culpeper's definition).

24 Bain (1979: 143).

25 Translation Hester (1993: 3) from Voltaire (1877: 24) (originally from 1719). The 'second act', in Voltaire's terminology, corresponds to the first episode, and includes the dialogue between Tiresias and Oedipus.

26 Wilamowitz-Moellendorff (1917: 78): 'sehr weit entfernt [...] von allen psychologischen Feinheiten'.

27 Reinhardt (1979: 104). 
As Edmunds notes,

The opening exchanges between Oedipus and Teiresias create an absurdist atmosphere in which one of the characters has come at the bidding of the other but then refuses to answer his questions. ${ }^{28}$

In the course of the scene, Tiresias repeats his refusal several times $\left(3^{28}-3^{29}\right.$, $\left.33^{2}-333,343^{-344}\right)$; he then, in fact, reveals what he knows $\left(35^{\circ}-353,362,366-\right.$ $367,413-428)$. When he finally walks away, he says:

\section{[2] Sophocles Oedipus the King 447-448

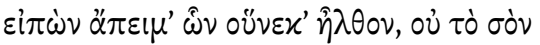

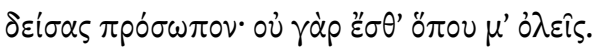

I will go when I have said what I came here for, not fearing your face; for there is no way that you can destroy me.

Does he mean that he came with the purpose of telling what he refused to tell? Or does he simply mean that he said what he was asked to come for? The first interpretation is far more plausible, as he hints at fear of Oedipus as a possible reason for not saying 'what he came for'. The interpretive problem centres on Tiresias' intentions and states of minds.

Interpreters offer different explanations for the perceived incoherence; these can be divided into four different general categories:

(a) there is an inconsistency at the level of characterisation; it has dramatic purposes; ${ }^{29}$

(b) there is an inconsistency, but it is to be explained as an instance of characterisation; 30

(c) the inconsistency is apparent: Tiresias is manipulating Oedipus and only feigns reticence; ${ }^{31}$

28 Edmunds (2000: $34-35)$.

29 Wilamowitz-Moellendorff (1917: 78); Finglass (2018: ad 447-448): 'Formal inconsistency is outweighed by dramatic gain'; Lloyd (2018: 339): 'the play could not continue if Oedipus had immediately accepted Tiresias' statements of his true identity (от 362 etc.), although this does not rule out an additional explanation in terms of character.'

30 Reinhardt (1979: 104); Lattimore (1975: 108); Bain (1979: 143); Roisman (2003: 4-5).

31 Ahl (1991: 67-102). 
(d) there is an inconsistency, but it is not related to characterisation or dramatic gain; it is determined by the logically impossible coexistence of freedom and fate within the storyworld of the play. ${ }^{32}$

A different explanation can be advanced:

(e) Tiresias is (apparently) incoherent because he faces a very difficult linguistic task.

In fact, Tiresias must break strong linguistic taboos if he is to reveal the truth (see the analyses in sections 5 and 6). Tiresias explains that he must overcome the 'fear' for the 'face' of Oedipus (see [2]). He first resists disclosing what he knows and only under strong verbal aggression from Oedipus does he reveal the truth. At the end of the scene, he attributes the intention of revealing the truth to himself, either as a post-factum explanation or as a revelation of a strategy he had in mind from the beginning. An analysis in terms of politeness strategies helps make sense of the 'incoherence'.

The four approaches listed above (a-d) will be analysed in inverted order. Section 3 will use possible-world theory to discuss whether the incoherence is logically inevitable or not (interpretation d). Section 4 will use ToM to discuss whether Tiresias is manipulating Oedipus (interpretation c). Sections 5 and 6 will use politeness theory and ToM to discuss the linguistic hurdles faced by Tiresias and to offer a linguistic analysis of the scene (interpretations a, b, and, especially, e).

Are incoherencies inevitable within the storyworld of the play? Dorati argues that that is the case. He notes that, in a partially determined storyworld,

it is always possible to imagine normal anthropomorphic actions (Achilles kills Agamemnon [...]) or different material circumstances (Oedipus and Laius fail to meet at the crossroad) that are in contrast with it [fate $]^{33}$

However, Dorati argues that, at the beginning of the play, the audience does not know whether the storyworld is determined or not. ${ }^{34}$ This is questionable:

32 Dorati (2015: 205-209). Manuwald (2012a: ad 316-318) also stresses that Tiresias could not have revealed the truth in the past, since this would have made the plot impossible. Manuwald (2012a: ad 447-448) and Manuwald (2012b) eliminates the incoherence of 447448 by deleting the whole sequence 447-462, but see Finglass (2018: $a d$ 447-462).

My translation from Dorati (2015: 39).

34 Dorati (2015: 39, 256-257). 
as Aristotle noted, some events in tragedy are fixed and inevitable as opposed to what happens in comedy (Poetics 1453a17-22 and 39). At the beginning of the play, characters presuppose that they can act freely: the verdict of Apollo reported by Creon implies that the citizens of Thebes are free to act and terminate the plague, and Oedipus' edict, banning the killer of Laius and threatening the accomplices, presupposes that people can choose their course of action. ${ }^{35}$ However,

[t]he entrance on stage of a mantis - a man that places himself on the same level as the god for knowledge (284ff.) - reveals further internal contradictions within the storyworld. Tiresias poses again and amplifies at the human level the problem posed by Apollo at the divine level. [...] The question Oedipus will later ask Creon (568f.) - if Tiresias knows, why does he not speak? - is symmetrical to that asked of Oedipus by the chorus leader about the role of Apollo [278-281]. ${ }^{36}$

The dialogue between Oedipus and Creon is especially telling:

[3] Sophocles Oedipus the King 568-569

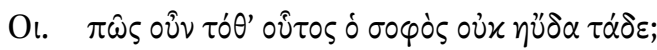

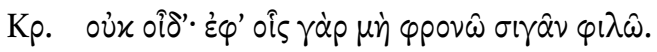

Oe. Why then did this wise man not declare these things at the time?

Cr. I do not know; on matters where I do not understand, I like to be silent. ${ }^{37}$

As Dorati points out:

Oedipus' accusations highlight a crucial problem [...]. If Tiresias is omniscient $[\ldots]$ and decided not to speak for some reason, why did he come onstage only to refuse to speak, and, at least according to his original intentions, to go back right away without revealing what he knows? ${ }^{38}$

Already Aristotle (Eth. Nic. 1113b21-26) points out that punishments imposed by legislators presuppose that actions depend on human beings and are voluntary.

36 My translation from Dorati (2015: 257).

37 Was this the source of Wittgenstein's 'Wovon man nicht sprechen kann, darüber muss man schweigen'?

38 My translation from Dorati (2015: 206). 
The problem is that the storyworld of the play combines a modicum of freedom with a large number of events determined by fate.

Prophetic abilities also pose a difficulty. Why does Tiresias not act to prevent parricide and incest? Why did he not solve the riddle of the Sphinx (391-398; see also $562-565$ )? Oedipus infers from this that Tiresias is not a true prophet (390-394), but the audience knows that Tiresias does indeed possess prophetic knowledge, as Oedipus will later realise (747). According to Dorati, these questions point to an impossibility in the storyworld of Oedipus the King: it is impossible to avoid fate, but Sophocles minimised the intervention of the gods within the play. ${ }^{39}$

One could explain the events of the play on the hypothesis that the gods intervene at the right moment in the story; for instance, we can infer that Apollo does not let Tiresias know what would stop the course of action envisaged by Apollo himself. ${ }^{40}$ This would imply that the gods are malevolent. Dorati rules this out, ${ }^{41}$ but there is internal ${ }^{42}$ and external evidence to the contrary. ${ }^{43}$

Moreover, the audience does not need to suppose that Tiresias is omniscient. Oedipus and the chorus presuppose that he 'grasp[s] all things' (300: see [6]) and that he knows everything that Apollo knows (284-286: see [7]), but these statements come from human, not divine, sources and are only part of a politeness strategy. ${ }^{44}$ One can infer that Apollo did not reveal to Tiresias how to solve the enigma of the Sphinx precisely because the god (377) 'takes an interest' (377 $\mu \dot{\varepsilon} \lambda \varepsilon \iota)$ in bringing Oedipus to his downfall, as Tiresias himself reveals:

39 Dorati (2015: 226).

40 See Kovacs (2009).

41 Dorati (2015: 175).

42 See [4] discussed below; Dodds (1966: 44-46 = 1973: 73-74); Cairns (2013: 127-138, 159, and passim); Kovacs (2019: 108-109), discussing [4], and lines 720-722, 1329-1333.

43 Soph. Trach. 1278, which is the final line of the play, states that 'no element of this was not

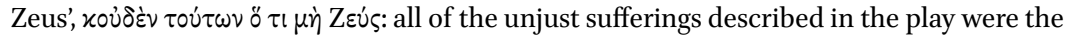
action of Zeus.

44 See below, section 6 . Note that in 305-309, Oedipus explains that he does not presuppose that Tiresias knows the response of the oracle reported by Creon; Oedipus suspects that Tiresias heard the news but cannot be sure about it. As Finglass (2018: ad 305-309) notes, Oedipus' statement 'if indeed you have not heard this from the mes-

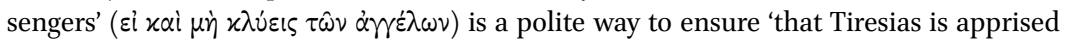
of the situation, without implying that the all-knowing seer is ignorant'; the introductory words $\varepsilon i$ xal 'if indeed' can be used 'in a protasis that the speaker suspects to be false'. 
[4] Sophocles Oedipus the King 376-377

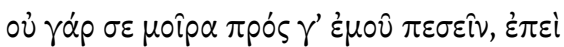

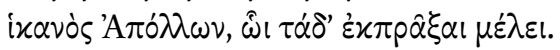

Indeed, since it is not fated that you should fall by my hand, since Apollo is sufficient, who takes an interest in bringing that to its conclusion. ${ }^{45}$

Tiresias does not reply to Oedipus' accusation at 390-394 about his failure to solve the riddle of the Sphinx because he does not want to damage his own 'positive face' by admitting partial ignorance in a confrontation that focuses on the reliability of his own prophetic skills. The prophet only knows what Apollo reveals to him when Apollo sees fit. ${ }^{46}$ This does not imply that Tiresias knew everything from the beginning. In fact, we only know that Tiresias knows the truth about Oedipus at the moment when the play takes place; we are never told that he knew Oedipus' fate in the past. From 376-377 ([4]), we positively know that Apollo is a 'malevolent' god who is intent on causing the fall of Oedipus. This explains why Tiresias' prophetic abilities cannot prevent fate.

\section{$4 \quad$ Tiresias the Manipulator?}

Another approach to the problem, a very extreme one, was suggested by Ahl. ${ }^{47}$ According to Ahl, there is no inconsistency in the scene: Tiresias always meant to reveal his message; his message is false; he only pretends to have access to divine revelations, but in fact he is part of a plot and wants to convince Oedipus of his guilt. Extreme interpretations such as Ahl's are fascinating because they explore the limit of our ToM. Murnaghan, in response to Ahl, points out

45 Finglass (2018) ad loc. translates 'whose business it is to bring that to its conclusion'.

46 On the role of Apollo in the play, see Cairns (2013: 127-138 and passim), Kovacs (2009), (2019). As Gunther Martin points out to me (in a personal communication), 'I believe we do not know what a seer sees when', nor could any non-seer in antiquity know what a mythical seer saw. This of course 'opens the doors for the poet to manipulate information and plots'; 'trying to construct a coherent view may be doomed to fail'. In any case, the text, by posing the very interpretive problems we are addressing, is asking the audience to explore possible answers.

47 Ahl (1991). Goodhart (1978) already argued that Oedipus was innocent and Tiresias untrustworthy. 
that this kind of reading presupposes treating characters in literature as if they were part of real life. ${ }^{48}$ As Dodds put it:

There is only one branch of literature where we are entitled to ask such

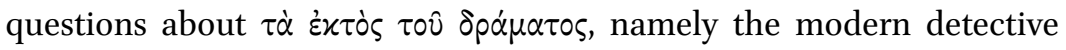
story. 49

This means that extreme interpretations use ToM in a way that seems illegitimate. However, we cannot completely abandon ToM when we interpret texts. Characters that act without motives and in a way that is unintelligible are not characteristic of Greek tragedy but of very different modern genres. ${ }^{50}$

In fact, ToM is crucial to the play. It is used by Oedipus in the first part of the play, when he, on the basis of his (false) belief in his own innocence, infers that Tiresias and Creon must have some other reasons for accusing him. Oedipus concludes that they are plotting against him in order to rob him of his kingdom $(380-403)$. He bases his confidence on his ability to 'read the mind' of the Sphinx when he solved the riddle. Even the chorus leader claims he reads the mind of Oedipus and Tiresias, namely when he 'conjectures' that the

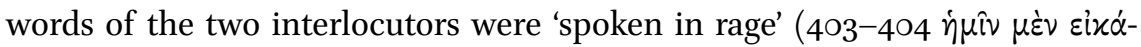

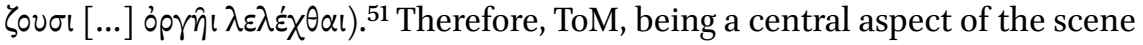
under discussion, cannot be completely dismissed as a tool for interpreting the play.

If we approach the scene from the politeness point of view of Tiresias and Oedipus, we find that they both have very difficult linguistic tasks.

The dynamics of power between the two interlocutors are unbalanced. Oedipus has supreme political power but Tiresias has a special connection with the gods. There is no established hierarchy between these two powerful people. Tiresias himself points out the ambiguity in ranking:

48 Murnaghan (1993: 164). For a brief but persuasive criticism of Ahl (1991), see Bain (1993).

49 Dodds (1966: 40-41 = 1973: 68).

50 See Easterling (1973): a classic paper on the 'human intelligibility' of tragic characters. On characterisation in antiquity, see now De Temmerman and van Emde Boas (2018) with further references.

$5^{1} \quad$ On anger in the play, see below, p. 199 n. 57. 
[5] Sophocles Oedipus the King 408-411

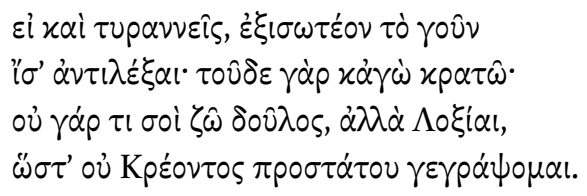

Even if you are a monarch, the right of equal reply must be equalised, at least; for of that I too am master. For my life is enslaved not at all to you, but to Loxias; so I will not be inscribed as having Creon as my patron.

Tiresias does not claim to be superior to Oedipus but equal. Ranking of power is a crucial sociolinguistic variable and of prime importance for im/politeness mechanisms. ${ }^{52}$ The lack of a precise ranking between the two speakers leads to frank and explicit verbal exchanges and makes the situation potentially explosive from a linguistic and social point of view, as the two interlocutors vie for linguistic and political supremacy.

Clashes between prophet and king are common in Greek epic and tragedy as well as in other genres and literatures..$^{53}$ One could ask whether a prophet feels the need to be perceived as polite by his interlocutors (politenessi: in this section 'politeness' and 'polite' will be used in this meaning): a prophet is after all protected by the gods and reveals the messages or even the very worlds he receives from the gods. ${ }^{54}$ However, from the very beginning of Homer's Iliad, we learn that priests and prophets need to speak with caution in front of a king for fear of retaliation (1.17-32, 62-115). This implies the need for facework from the prophet.

Moreover, Oedipus has access to special intellectual abilities which make him think he is, in some respects, more authoritative than the prophet; these abilities push him to extremes in attributing intentions to other agents, using ToM to an unprecedented level. Finally, Tiresias and Oedipus are speaking in front of a chorus of Theban citizens, and Tiresias must avoid using taboo words or expressions.

Oedipus, at the beginning of the scene, asks Tiresias to tell the truth. Tiresias faces three politeness problems. First of all, if he accepts to do what Oedipus

$5^{2}$ Brown and Levinson (21987: 29-33, 74-83, and passim); Culpeper (2011: 186-193 and passim).

53 See e.g. Bremmer (1993). On the roles of prophet and king in this scene, see Worman (2014: sections 6-7).

54 I thank M. Lloyd for this observation. 
asks him to do, he must threaten the negative face of Oedipus. Tiresias has to tell Oedipus that he must leave town (as a consequence of his own edict). Secondly, Tiresias must also make admissions that threaten his own negative face: he is asked by Oedipus to admit his inability to help now and in the past. Thirdly, and more importantly, if the prophet is to reveal what happened, he must attack the 'positive' face of Oedipus and break several linguistic taboos. He must tell Oedipus that

(a) he is a murderer;

(b) he is the murderer of Laius, i.e. he is the person that he himself banned from the city;

(c) he committed parricide since Laius is his father;

(d) he committed incest since Jocasta, his wife, is in fact his mother.

These are all extreme aggressions to the positive face of Oedipus. In fact, 'par-

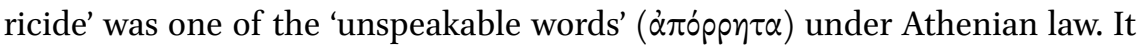
was, from a legal point of view, a taboo word. The person making a (false) accusation of parricide could be brought to trial. ${ }^{55}$ Within the drama, incest is perceived as being linguistically even more problematic than parricide. At the end of the play, the messenger pronounces the word 'parricide' (1288 $\pi \alpha \tau \rho \circ-$ $x \tau$ tovov) but cannot bring himself to repeat the terms Oedipus used to describe the nature of his relation to his mother (note the harsh aposiopesis at 1289: tòv

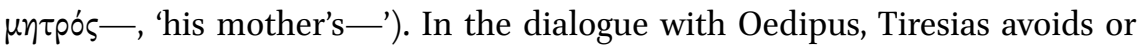
delays revealing explicitly what Oedipus did. This linguistic approach can be interpreted both as a politeness strategy ('off record') and as a social strategy (avoiding words that are unacceptable in some social contexts: euphemism). ${ }^{56}$ These two possibilities are not in principle mutually exclusive, but in this case, politeness can be ruled out: Tiresias repeatedly clarifies that it is only anger that makes him reveal the facts (412 [13]), ${ }^{57}$ and he is reluctant to explain what happen explicitly. His euphemistic statements are therefore not a politeness strategy directed to Oedipus.

55 See Lys. 10.6 with Todd (2007: ad loc.); Clay (1982).

56 On euphemism in ancient Greece, see Sommerstein and De Martino (1999), Pellucchi (2013), Caroli (2017), with further bibliography.

57 Oedipus repeatedly mentions that Tiresias made him angry (335, 339, 345), and Tiresias comments on Oedipus' anger $(337-338,344)$. Anger is often seen as causing bad deliberations: see Thuc. 3.42.1 and, in the context of impolite accusations to an interlocutor, Eur. Med. 446-447, 615. See Battezzato (2017: 169). On anger in this scene, see Worman (2014: section 6). On conceptions of anger in antiquity, see Harris (2001), Braund and Most (2003). 
A general overview of the scene shows that, after an initial positive politeness act from Oedipus (300-315) and an off-record reply from Tiresias (317-319), both interlocutors speak 'bald on record' with occasional attempts at negative politeness from Oedipus ('give reasons': 303, 305-314) and frequent off-record and ironic utterances from Tiresias. Tiresias' off-record utterances include a general maxim (spoken in order to avoid answering a request [317-319]), indirect revelations about Oedipus' fate $\left(35^{\circ}-353,366-367,372-373,379,413-428\right.$, $438,442)$, and ironic utterances $\left(364,432,435^{-436}\right.$, an ironic indirect accusation, 440). The difficulties of Tiresias' linguistic task will emerge from a detailed analysis of the scene.

Oedipus starts the dialogue by failing to understand the gravity of the linguistic problems of his interlocutor; he nonetheless appreciates that his request is a threat to the negative face of Tiresias. For this reason, Oedipus tries to mitigate the face threat with standard positive politeness techniques. He welcomes the seer expressing exaggerated praise:

[6] Sophocles Oedipus the King 300-301

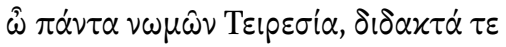

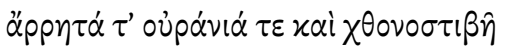

Tiresias, you who grasp all things, what can be taught and what cannot be spoken, the things of heaven and the things that tread the earth

As Finglass observes: "Tiresias attempts to leave words unspoken that Oedipus wishes to be said. ${ }^{58}$ More than that: by mentioning the need to speak 'what

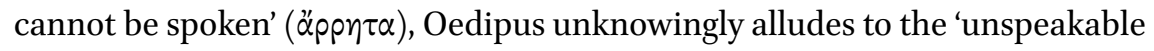
words' ( $\dot{\alpha} \pi \dot{\rho} \rho p \eta \tau)$, i.e. to the accusation of parricide.

In his positive facework, Oedipus echoes a similar statement made earlier by the chorus:

[7] Sophocles Oedipus the King 284-286

$\alpha^{\prime \prime} \nu \alpha x \tau^{\prime} \ddot{\alpha} \nu \alpha x \tau i \tau \alpha \theta^{\prime} \theta^{\prime} \dot{\rho} \rho \hat{\omega} \nu \tau^{\prime} \dot{\varepsilon} \pi i \sigma \tau \alpha \mu \alpha \iota$

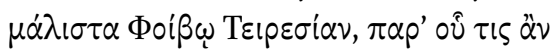

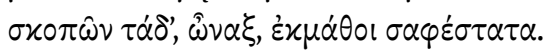

$5^{8} \quad$ Finglass (2018: $a d$ 30o-301). 
I know that lord Tiresias sees the same things as does lord Phoebus, and from him, my lord, one might learn these things most truly in the course of investigation.

The words of Oedipus and the chorus leader do not imply that Tiresias is in fact omniscient, as Dorati and others concluded. ${ }^{59}$ The chorus leader praises Tiresias' prophetic ability as part of his attempt to mitigate the face threat he is making in telling Oedipus what he should do (see already the tentative question of the chorus leader at 282). Oedipus' words can simply be interpreted as an instance of positive politeness: they introduce the request (made at 310-315) that the prophet use all his prophetic arts to help discover the identity of the murderer of Laius.

At the beginning of the dialogue, Oedipus thus mitigates the face threats by using positive politeness, namely by praising Tiresias' prophetic abilities (300301,304 ) and negative politeness ('give reasons') when he orders him to speak $(303,305-314)$. The city is in danger: therefore, Tiresias must speak (310-315). This request puts him in a difficult situation. He reacts with-what conversation analysis calls - a 'pre-expansion', in which he gives reasons for the refusal that he will make explicit at $328-329$ :

[8] Sophocles Oedipus the King 316-318

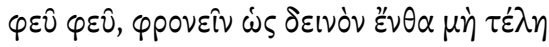

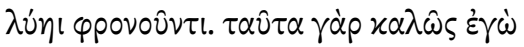

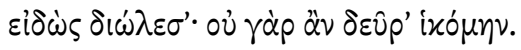

Pheu pheu, how terrible is wisdom when being wise brings no advantage! I knew this well but forgot it; for otherwise I would not have come.

The interjection pheu pheu and the (exact) wording of these remarks allow the interlocutors to draw an inference about Tiresias' state of mind: he is 'emotionally upset' (Bain 1979: 134). His language is peculiar: he says he 'destroyed' ( $\delta\left(\omega \dot{ } \lambda_{\varepsilon \sigma \sigma \alpha)}\right.$ his knowledge, a verb that many interpreters consider as equivalent to 'forgetting'.60 Other scholars suggest that Tiresias is saying that

59 Dorati (2015: 205).

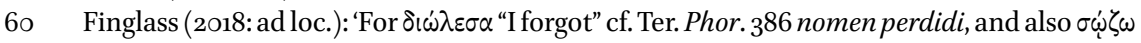
"I remember" at Eur. Hel. 266 (and LSJ ${ }^{9}$ s.v. $\sigma \omega \dot{\zeta} \zeta \omega$ i 4 [the second 4 under i] for $\sigma \dot{\omega} \zeta 0 \mu \alpha$ l with this sense); perhaps the unusual term somehow emphasises Tiresias' personal agency in 
"Teiresias, for his part, did not "forget" this conventional wisdom [...] but deliberately put it out his mind, in order to comply with Oedipus' summons' (Edmunds 2000: 37). ${ }^{61}$ This ambiguous statement amounts to an off-record response.

The dialogue rapidly escalates into an angry argument. Oedipus immediately attacks Tiresias' face with a bald on record statement, accusing him of 'breaking the law' and acting as an enemy of the city that reared him (322$333)$. Tiresias tries to explain that Oedipus' request is inopportune (324-325), a typical positive polite strategy ('give reasons'). ${ }^{62}$ Oedipus supplicates the prophet, thus applying the strongest religious pressure he can $\left(3^{26-327)}\right)^{63}$ Tiresias utters his first direct ('bald-on-record') statement, claiming that Oedipus and the citizens of Thebes lack understanding (328). He categorically refuses to reveal what he knows (329), a stance that Oedipus considers tantamount to treason (330-331). Tiresias states, once again, his refusal (332-333), which makes Oedipus break into open coercive impoliteness:

[9] Sophocles Oedipus the King 334-336

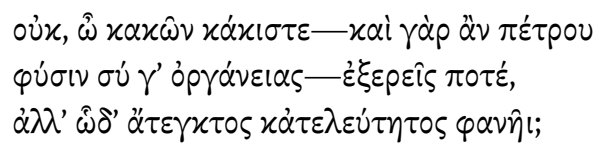

You utter wretch - for you would enrage a very stone-will you never speak out? Will you appear thus intransigent and inconclusive?

Oedipus points out that Tiresias' behaviour is provocative: the prophet's words cause anger in him. ${ }^{64}$ But is Tiresias being intentionally provocative? Or is this just a consequence of his intention to avoid threatening Oedipus' 'face'? The exchange that follows focuses on Oedipus' anger (337-343) and concludes with another bald-on-record refusal from Tiresias, who defiantly challenges Oedipus to rage as much as he likes (344-345). Oedipus takes up the challenge and reveals what he had been thinking already for a while:

suppressing the thought more than e.g. $\delta\llcorner\varepsilon \lambda \alpha \theta o ́ \mu \eta \nu$ would.' The lack of Greek parallels is striking.

61 For a discussion of the interpretations, see Dorati (2015: 206 n. 205, 207 n. 201 and 203).

62 Brown and Levinson (21987: 128-129).

63 On supplication, see Gould (1973), Naiden (2006).

64 See above n. 57 . 
[10] Sophocles Oedipus the King 345-346

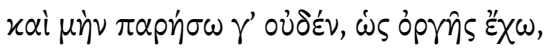

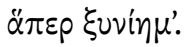

Well, I will leave out nothing — such is my anger—of what I understand.

This utterance marks a turning point in the scene: Oedipus, saying that he 'will leave out nothing', reveals his previous and future linguistic strategies. ${ }^{65}$ Until this moment he has 'left out' something, i.e. he has not completely revealed his thoughts. It is his present state of anger, which he has just reached ('such is my anger'), that allows him to say what he thinks. Anger allows him to express the face-threatening utterances that he had repressed so far. Oedipus goes on to accuse Tiresias of being an accomplice in the murder of Laius (346-349), a grave accusation, which entails exile or death. These violent attacks to Tiresias' face take the conversation away from all politeness strategies, which in turn allows Tiresias to speak the truth. Tiresias crosses the first linguistic boundary, explicitly accusing Oedipus of being the murderer of Laius (above, section 5, p. 199: points [a] and [b]). However, he only indirectly accuses Oedipus of being the murderer of Laius; he states that the king is the "unholy polluter of the

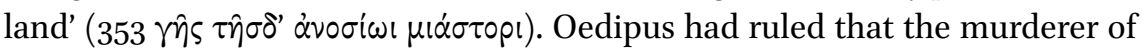
Laius, because of his impure status, should be excluded from any conversation with the citizens of Thebes (238), and Tiresias states that any conversation with Oedipus should stop now $\left(35^{\circ}-353\right)$. The prophet stresses that it was Oedipus who forced him to speak:

\section{[11] Sophocles Oedipus the King $35^{8}$

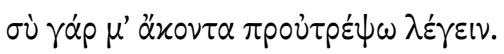

For you made me speak although I was unwilling.

Tiresias' revelation becomes explicit (362) at Oedipus' request (361). After this, Oedipus crosses another boundary and resorts to physical threats (363). This menaced aggression makes Tiresias in turn cross another linguistic boundary (above, section 5, p. 199, [e]): the prophet finally hints at Oedipus' incest:

65 On some such strategies, see van Emde Boas in this volume. 
[12] Sophocles Oedipus the King 364-367

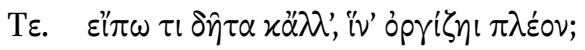

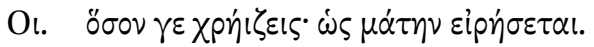

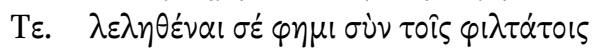

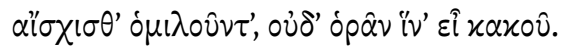

Ti. Shall I say anything else, then, so that you can get angrier?

Oe. As much as you like, as it will be spoken in vain.

Ti. I say that you are unknowingly associating most shamefully with those closest to you, and do not see in what a disaster you are.

Tiresias sarcastically asks Oedipus for permission, noting that he will make the king even angrier. In this way, no one can blame Tiresias for 'destroying' or 'forgetting' (318: [8]) what wise people know. Tiresias makes, as Catrambone notes, 'sarcastic use of the deliberative subjunctive' ( 364 'shall I say'), to which Oedipus replies 'with equally sarcastic positively-polite exaggeration' at $365 .{ }^{66}$ Tiresias stresses that he intends to stir Oedipus' anger (364 'so that you can get angrier'); he is able to control Oedipus' emotions, reactions, and language. Oedipus gives permission (365), erroneously thinking that he is in control, but must immediately resort to uttering further physical threats (368, repeating the threat of 363 ), and, finally, expressing disbelief (370-371, 374-375). Oedipus' disbelief culminates in a long speech where he denies that Tiresias has any sound knowledge of the past and the future, thus taking back what he said at the beginning of the episode ([6] = 300-301; 304); Oedipus questions Tiresias' prophetic ability and suggests that greed and lust for power motivate his words $(380-403)$. Tiresias answers with a symmetrical speech (408-428), where he specifies that he is speaking because Oedipus insulted him:

[13] Sophocles Oedipus the King 412

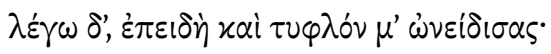

I speak, because you even insulted me as blind.

66 Catrambone (2019: 258 n. 408). For a similar request in a polite contest, see Eur. Supp. 293

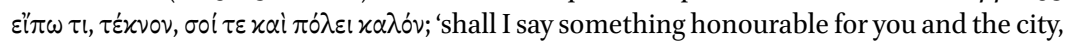
my son?' 
Tiresias thus states that he caused Oedipus' anger, which in turn caused Oedipus' insults, which allowed Tiresias to speak the truth. Tiresias' control of the dialogue is complete. His metalinguistic observation stresses anger again as a motivation for linguistic acts in continuity with similar previous observations by both speakers and the chorus leader $(335,337-338,339-340,364$ [12 ], 404405). Tiresias restates, in allusive and indirect language, that Oedipus 'does not see' (413) his situation and does not understand what he did to his father and mother. Tiresias finally resorts to direct attacks to the face of Oedipus, prophes-

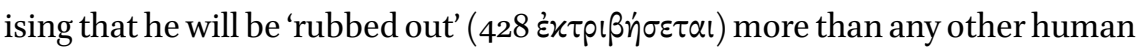
being. ${ }^{67}$

Oedipus rejects Tiresias' words as absurd insults and utters new threats against the prophet (429-431, 433-434). Tiresias replies by pointing out that it was Oedipus who asked him to come and speak (432) and claims that he will be considered 'wise' ( 436 है $\mu \varphi p o v \varepsilon \varsigma$ ) by Oedipus' parents. Oedipus asks who his parents are, and Tiresias answers that 'this day will be your parent'. This is an off-record reply, shifting the focus from the biological to the metaphorical level:

[14] Sophocles Oedipus the King 438-439

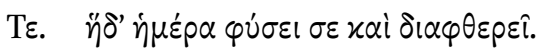

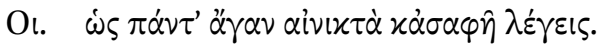

Ti. This day will be your parent and your destroyer.

Oe. How everything you say is full of riddles and obscurity!

Oedipus reads Tiresias' words as 'full of riddles', and this is consistent with Tiresias' role as a prophet. Oedipus, however, does not understand that Tiresias, even at this point of their clash, is, in fact, being euphemistic, i.e. not polite or prophetic. ${ }^{68}$ At 440 , Tiresias sarcastically alludes to Oedipus' pride in his ability to interpret riddles, in reference to 390-397, where Oedipus accused Tiresias of being a useless prophet because he was unable to solve the riddle of the Sphinx. This is another direct attack to Oedipus' face: Tiresias notes that Oedipus' abil-

67 Tiresias uses prosaic terms: see esp. $427 \pi \rho 0 \pi \eta \lambda \dot{\alpha} x \iota \zeta \varepsilon$ with Worman (2014: n. 12) and Finglass (2018: ad 426-428).

68 Brown and Levinson $\left({ }^{2} 1987: 217,223,226\right)$ discuss euphemisms as an off-record politeness strategy intended to minimise the face threat to the interlocutor. Here, Tiresias does not intend to minimise the face threat to Oedipus but elicits further questions from him, which will authorise Tiresias to use more explicit language. 
ity was in fact to his disadvantage (442) and implies that he is unable to use his ability to his own advantage now.

At this point, Tiresias expresses his intention to accept Oedipus' order and walk out (444) ${ }^{69}$ He delivers a final speech (447-462), introduced by the passage quoted above (see [2]), where he states his intention to reveal what he came for. Tiresias' revelations about incest and parricide finally become direct and explicit.

\section{[15] Sophocles Oedipus the King 457-46o}

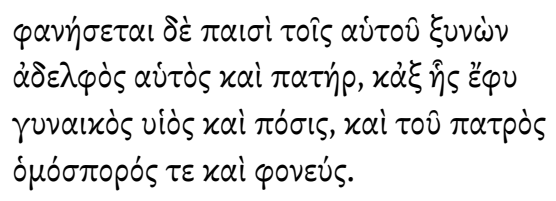

He will be revealed as both brother and father of the children he is living with, and the son and husband of the woman from whom he was born, and the fellow-sower and killer of his father.

Tiresias avoids using the taboo word 'parricide', which was considered extremely shocking; however, he resorts to a very explicit periphrasis ( $\tau 0 \hat{0}$

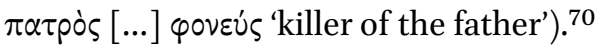

This scene ends in a walkout, as many arguments do in real life. ${ }^{71}$ Tiresias obeys Oedipus' order to leave the stage ${ }^{72}$ but has the last word in the scene: there is nothing that Oedipus can say at this point.

69 Oedipus orders Tiresias to leave at 430-431, stops him at 437 ( $\mu$ घivov 'stop!'), and orders him, once more, to leave at $445^{-446}$. Tiresias says he will leave at 444 but delivers his final speech $(447-462)$ before doing so.

70 Athenian law explicitly prohibited the slanderous use of the taboo word 'parricide'. The law was probably interpreted as prohibiting also the use of periphrases, as argued in Lys. 10: cf. above, section 5, p. 199 with n. 55. Oedipus, in any case, is a parricide (and therefore, one would assume, not covered by the law). He shockingly uses that very word ( $\pi \alpha \tau$ poxtóvov 'parricide') in reference to himself at 1288, in an indirect speech reported by the messenger. Plato Laws $944 \mathrm{~b}-\mathrm{e}$, in discussing 'shield-flinger', another word considered 'unspeakable' under Athenian law, stresses that periphrases or less common turns of phrases are felt to be less hurting and damning than the words covered by the law.

71 See the studies by Dersley and Wootton (2000) and Dersley and Wootton (2001).

72 See Finglass (2018: $a d$ 447-462) for a review of staging and authenticity problems. See also above, p. 193 n. 32 . 
We have now returned to our original question about ToM: is Tiresias' stated intention a post-factum explanation or a revelation of his original intention? Is Tiresias allowed to be 'insincere' in his refusal to speak? We find that a contemporary of Sophocles interpreted the Oedipus the King scene in this way. In Euripides' Phoenician Women, Creon summons Tiresias onstage, asking the prophet to reveal what he knows about the future. The prophet again refuses to speak:

[16] Euripides Phoenissae 891-895

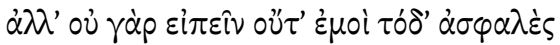

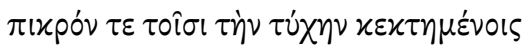

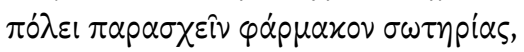

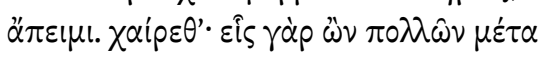

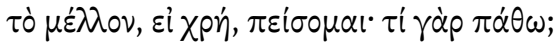

But it is unsafe for me to speak these words, and it will be galling to those who are touched by this fate that I should give the city its life-saving medicine: I'm going away. Farewell! If I must I will suffer, as one man among many, what is to come. What can I do? ${ }^{73}$

As Mastronarde and others noted, Euripides modelled this scene on that between Tiresias and Oedipus in Oedipus the King. ${ }^{74}$ In Euripides, Tiresias reinstates his refusal after Creon's repeated requests (896-897); however, when the king points out the need to help the city in peril $(898,900)$, he rapidly accedes to the king's request. Tiresias repeatedly asks his interlocutor to confirm his will to know the truth, especially in the presence of his son (901-910). Tiresias' shift from refusal (891-895) to compliance (910) occurs in the span of a very brief dialogue ( 85 words in lines $891-909) .{ }^{75}$ This suggests that Tiresias only meant to obtain preventive reassurances from Creon. For he was afraid he might face Oedipus' anger when confronting him with the possibility of negative con-

73 Translation from Kovacs (2002).

74 Mastronarde (1994: ad 865-895) and Medda (2006: 46-5o, 219 n. 156), with further references.

75 The dialogue might have been even shorter since lines 903-904 are suspected of being unauthentic by some scholars: see, however, Mastronarde (1994) and Medda (2006: ad loc.). 
sequences. The linguistic difficulties are much weaker here than in Oedipus the King: Tiresias is about to reveal that the king's son needs to be sacrificed if the city is to be saved, but no shameful secrets or accusations are involved, nor is the king forced to act on the revelation because of a binding legal and religious commitment he himself proclaimed in public, as in Oedipus the King. ${ }^{76}$

Of course, the king is expected to act on behalf of the city, but the threats to the positive and negative face of the king are much weaker than in Sophocles. In Euripides, Tiresias' refusal is meant to show solidarity with, not hostility against, the king; his words (see [16]) imply that he is willing to die rather than make revelations that can lead to the death of the king's son.

Euripides, in recreating the scene from Oedipus the King, simplifies the linguistic challenges for the speakers and the interpretive problems for the audience: he creates a dialogue that clearly suggests that the prophet meant to reveal what he knew if he received appropriate reassurance. Does this interpretation work for the Oedipus the King scene as well? In Oedipus the King, we are left without conclusive evidence on whether Tiresias attributes to himself the intention of revealing the truth only post factum or whether this was his intention all along.

Based on psychological parallels, interpreters may conclude in favour of the post-factum explanation, which is compatible with the claim that the scene contributes to the characterisation of the two interlocutors.

Alternatively, one can offer a weaker version of the insincerity interpretation advanced by Ahl (1991): Tiresias meant to reveal his message from the beginning, thus saving the city, but felt he could not do this because of the face threats involved and the linguistic taboos he had to break. The prophet revealed the truth only when compelled by Oedipus' anger, which the prophet himself caused. This may imply that he elicited Oedipus' anger on purpose. In this interpretation, Tiresias in Oedipus the King is being insincere when he states that he wants to leave without revealing the truth. A true prophet that is insincere may sound paradoxical. But, as we saw in Euripides' Phoenician Women, it is not unparalleled.

Prophets are proverbially obscure; audiences expect them to clash with kings. The text of Sophocles weaves these typical strands of characterisation into an unexpected tapestry: the obscurity is in fact not a divine challenge to human fallibility, but a necessary choice under complex circumstances. Oedipus fails to decipher Tiresias' obscurity, just as he failed to decipher Apollo's

76 The king, in fact, tries to avoid the death of his son, who eventually kills himself to save the city: Eur. Phoen. 985-1012. 
prophecy. Mistakenly overconfident in his ability to read the mind of the prophet, he ironically breaks the linguistic barrier of respect and politeness, thus allowing Tiresias to deliver the message he asked for-and again failing to understand what Tiresias says in very plain words. The text thus exploits the external constraints of the communicative situation by making Tiresias' clarity appear opaque to an Oedipus who is led astray by his own interpretive fury.

The storyworld of Oedipus the King is partially determined by fate and we must assume that the gods intervene to avoid outcomes that do not conform to fate or predictions. This helps to make sense of Tiresias' initial statement about the uselessness of advance knowledge. Tiresias' linguistic difficulties help understand why he is reticent about his failure to help in the past: admitting the uselessness of his knowledge would be a threat to his own positive face.

We see how the linguistic interpretation of this scene is strictly linked to the themes of human freedom and fate, to the attribution of intent to human agents, and to the dynamics of linguistic interaction. That Tiresias is insincere is a possibility suggested but not made unambiguous by the text. Does this interpretation push ToM too far, as Dodds would claim? Or is thinking about language, fate, gods, and human freedom the whole point of Oedipus the King?

\section{References}

Ahl, F., (1991), Sophocles'Oedipus: Evidence and Self-conviction, Ithaca.

Apperly, I., (2012), Mindreaders: the Cognitive Basis of 'Theory of Mind', Hove/New York. Bain, D., (1979), 'A Misunderstood Scene in Sophokles, Oidipous (O.T. 300-462)', Greece \& Rome, 26, 132-145.

Bain, D., (1993), Review of Ahl 1991, The Journal of Hellenic Studies 113, 189-19o.

Barrios-Lech, P., (2016), Linguistic Interaction in Roman Comedy, Cambridge.

Battezzato, L., (2017), 'Change of Mind, Persuasion, and the Emotions: Debates in Euripides from Medea to Iphigenia at Aulis', Lexis 35, 164-177.

Battezzato, L., (2019), Leggere la mente degli eroi: Ettore, Achille e Zeus nell'Iliade, Pisa. Braund, S.M. \& Most, G.W. (eds.), (2003), Ancient Anger: Perspectives from Homer to Galen, Cambridge.

Bremmer, J.N., (1993), 'Prophets, Seers, and Politics in Greece, Israel, and Early Modern Europe', Numen 40, 150-183.

Brown, H.P., (2006), 'Addressing Agamemnon: a Pilot Study of Politeness and Pragmatics in the "Iliad"', Transactions of the American Philological Association 136, 1-46.

Brown, P. \& Levinson, S.C., ( ${ }^{2} 1987$ [1978]), Politeness: some Universals in Language Usage, Cambridge. 
Budelmann, F. \& Easterling, P.E., (2010), 'Reading Minds in Greek Tragedy', Greece \& Rome 57, 289-303.

Cairns, D., (2013), 'Divine and Human Action in the Oedipus Tyrannus', in D. Cairns (ed.), Tragedy and Archaic Greek Thought, Swansea, 119-171.

Caroli, M., (2017), Il velo delle parole:l'eufemismo nella lingua e nella storia dei Greci, Bari.

Catrambone, M., (2016), 'Off-record Politeness in Sophocles: the Patterned Dialogues of Female Characters', Journal of Politeness Research 12, 173-195.

Catrambone, M., (2019), Tragic Conversation: Politeness Strategies in Sophocles' Patterned Dialogues, PhD Thesis (Scuola Normale Superiore, Pisa).

Clay, D., (1982), 'Unspeakable Words in Greek Tragedy', The American Journal of Philo$\operatorname{logy} 103,277-298$.

Condello, F., (2016), Sofocle: Edipo Re, Santarcangelo di Romagna.

Culpeper, J., (2011), Impoliteness: Using Language to Cause Offence, Cambridge.

De Temmerman, K. \& van Emde Boas, E., (2018), Characterization in Ancient Greek Literature, Leiden.

Dersley, I. \& Wootton, A.J., (200o), 'Complaint Sequences within Antagonistic Argument', Research on Language and Social Interaction 33, 375-406.

Dersley, I. \& Wootton, A.J., (2001), 'In the Heat of the Sequence: Interactional Features Preceding Walkouts from Argumentative Talk', Language in Society 30, 611-638.

Dodds, E.R., (1966), 'On Misunderstanding the Oedipus Rex', Greece \& Rome 13, 3749 (repr.: The Ancient Concept of Progress and Other Essays on Greek Literature and Belief, Oxford 1973, 64-77).

Dorati, M., (2015), Finestre sul futuro: fato, profezie e mondi possibili nel plot dell'Edipo re di Sofocle, Pisa.

Easterling, P.E., (1973), 'Presentation of Character in Aeschylus', Greece \& Rome 20, 3-19. Edmunds, L., (2000), 'The Teiresias Scene in Sophocles' Oedipus Tyrannus', Syllecta Classica 11, 34-73.

Emde Boas, E. van, (2017a), 'Analyzing Agamemnon: Conversation Analysis and Particles in Greek Tragic Dialogue', Classical Philology 112, 411-434.

Emde Boas, E. van, (2017b), Language and Character in Euripides' Electra, Oxford.

Epley, N., (2014), Mindwise: how we Understand what Others Think, Believe, Feel, and Want, New York.

Ferri, R., (2009), 'Politeness in Latin Comedy: some Preliminary Thoughts', Materiali e discussioni per l'analisi dei testi classici $61,15^{-28}$.

Finglass, P.J., (2018), Sophocles, Oedipus the King, Cambridge.

Gianquinto, A., (1994), 'Strategie della memoria: Tiresia ad Atene. I vv. 316-318 dell'Edipo Re', Orpheus 15, 430-443.

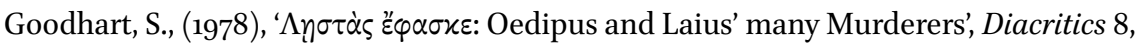
55-71.

Gould, J., (1973), 'HI KetEIA', The Journal of Hellenic Studies 93, 74-103. 
Grice, P., (1975), 'Logic and Conversation', in P. Cole \& J.L. Morgan (eds.), Speech Acts, New York, 41-58 (repr.: Studies in the Way of Words, Cambridge, Mass./London 1989, 22-40).

Hall, J., (2009), Politeness and Politics in Cicero's Letters, Oxford/New York.

Harris, W.V., (2001), Restraining Rage: the Ideology of Anger Control in Classical Antiquity, Cambridge/Mass.

Haugh, M., (2008), 'Intention in Pragmatics', Intercultural Pragmatics 5, 99-110.

Haugh, M. \& Jaszczolt, K.M., (2012), 'Speaker Intentions and Intentionality', in K.M. Jaszczolt and K. Allan (eds.), The Cambridge Handbook of Pragmatics, Cambridge, 87112.

Heath, M., (1987), The Poetics of Greek Tragedy, London.

Herman, D., (2013), 'Cognitive Narratology', in P. Hühn (ed.), The Living Handbook of Narratology (Hamburg). https://www.lhn.uni-hamburg.de/node/38.html [26/o4/ 2019].

Hester, D.A., (1993), 'The Ignorance of Oedipus', Prudentia 25, 1-23.

Heyes, C. (ed.), (2018), Cognitive Gadgets: the Cultural Evolution of Thinking, Cambridge/Mass.

Iser, W., (1978), The Act of Reading: a Theory of Aesthetic Response, Baltimore.

Iurescia, F. \& Martin, G., (2019), 'Conversational Strategies across Greek and Roman Tragedies', Lingue e Linguaggi 31, 233-254

Kahneman, D., (2011), Thinking, Fast and Slow, New York.

Kovacs, D., (2002), Euripides, vol. 5, Cambridge, Mass./London.

Kovacs, D., (2009), 'The Role of Apollo in Oedipus Tyrannus', in J.R.C. Cousland \& J.R. Hume (eds.), The Play of Texts and Fragments: Essays in Honour of Martin Cropp, Leiden, 357-368.

Kovacs, D., (2019), 'On Not Misunderstanding Oedipus Tyrannos', Classical Quarterly 69, $107-118$.

Lattimore, S., (1975), 'Oedipus and Teiresias', California Studies in Classical Antiquity 8, $105^{-111 .}$

Lloyd, M., (2004), 'The Politeness of Achilles: Off-record Conversation Strategies in Homer and the Meaning of kertomia', The Journal of Hellenic Studies 124, 7589 .

Lloyd, M., (2006), 'Sophocles in the Light of Face-threat Politeness Theory', in I.J.F. de Jong and A. Rijksbaron (eds.), Sophocles and the Greek Language: Aspects of Diction, Syntax and Pragmatics, Leiden/Boston, 225-239.

Lloyd, M., (2009), 'The Language of the Gods: Politeness in the Prologue of the Troades', in J.R.C. Cousland \& J.R. Hume (eds.), The Play of Texts and Fragments: Essays in Honour of Martin Cropp, Leiden, 183-192.

Lloyd, M., (2018), 'Sophocles', in K. De Temmerman and E. van Emde Boas, 337-354.

Manuwald, B., (2012a), Sophokles, König Ödipus, Berlin. 
Manuwald, B., (2012b), 'Wann verlässt Ödipus die Bühne? Zum Schluss der TeiresiasSzene in Sophokles' König Ödipus', Rheinisches Museum für Philologie 155, 128-141.

Mastronarde, D.J., (1994), Euripides, Phoenissae, Cambridge.

Medda, E., (2006), Euripide, le Fenicie, Milan.

Murnaghan, S., (1993), Review of Ahl 1991, Classical Philology 88, 162-167.

Naiden, F.S., (2006), Ancient Supplication, Oxford/New York.

Pellucchi, T., (2013), 'Euphemism and Dysphemism', in G.K. Giannakis and V. Bubenik (eds.), Encyclopedia of Ancient Greek Language and Linguistics, vol. 2, Leiden, 582585 .

Pfeiffer-Petersen, S., (1996), Konfliktstichomythien bei Sophokles: Funktion und Gestaltung, Wiesbaden.

Reinhardt, K., (1979), Sophocles, Oxford (Engl. tr. of: Sophokles, Frankfurt a.M. ${ }^{4} 1976$ [1933]).

Roisman, H.M. (2003), 'Teiresias, the Seer of Oedipus the King: Sophocles' and Seneca's Versions', Leeds International Classical Studies 2.5. https://web.archive.org/web/2O14 1129151559/http://lics.leeds.ac.uk/2003/200305.pdf [13/08/2020].

Ryan, M.L., (1991), Possible Worlds, Artificial Intelligence, and Narrative Theory, Bloomington/Indianapolis.

Ryan, M.L. (2013), 'Possible Worlds', in P. Hühn (ed.), The Living Handbook of Narratology, Hamburg. https://www.lhn.uni-hamburg.de/node/54.html [26/o4/2019].

Sacks, H., Schegloff, E.A., \& Jefferson, G., (1974), 'A Simplest Systematics for the Organization of Turn-taking for Conversation', Language 5o, 696-735.

Scodel, R., (2012), ' $\hat{\eta}$ and Theory of Mind in the Iliad', in M. Meier-Brügger (ed.), Homer, gedeutet durch ein großes Lexikon, Berlin, 315-330.

Sidnell, J., (2010), Conversation Analysis: an Introduction, Malden.

Sidnell, J. \& Stivers, T., (2012), The Handbook of Conversation Analysis, Malden.

Sommerstein, A.H. \& De Martino, F. (eds.), (1999), Studi sull'eufemismo, Bari.

Todd, S.C., (2007), A Commentary on Lysias, speeches 1-11, Oxford.

Voltaire, (1877), OEuvres complètes: Théâtre, vol. 1, Paris.

Watts, R.J., (2003), Politeness, Cambridge.

Wilamowitz-Moellendorff, T. von, (1917), Die dramatische Technik des Sophokles, Berlin.

Worman, N., (2014), 'Oedipus Abuser: Insult and Embodied Aesthetics in Sophocles', Cahiers Mondes anciens 5. http://journals.openedition.org/mondesanciens/1237 [26/04/2019].

Zunshine, L., (2006), Why we Read Fiction, Columbus.

Zunshine, L. (ed.), (2015), The Oxford Handbook of Cognitive Literary Studies, Oxford. 